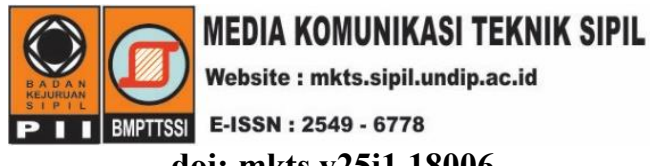

doi: mkts.v25i1.18006

\title{
Analisis Perkuatan Timbunan Di Atas Tanah Lunak Menggunakan Dinding Turap dengan Pendekatan Model Numerik
}

\author{
"Indra Noer Hamdhan ${ }^{1}$, Fauziah Fitriani Iskandar² \\ ${ }^{1}$ Fakultas Teknik Sipil dan Perencanaan, Institut Teknologi Nasional, Bandung \\ ${ }^{2}$ Program Studi Magister Teknik Sipil, Insititut Teknologi Bandung, Bandung \\ *) indranh@itenas.ac.id
}

Received: 14 Maret 2018 Revised: 9 Mei 2019 Accepted: 13 Mei 2019

\begin{abstract}
Embankment on soft clay may be affect settlement at subgrade, causing lateral deformation and vertical deformation around embankment. Therefore, reinforcement is needed to overcome the effects caused of the embankment. This research was conducted to find out the influence of sheet pile wall of embankment using PLAXIS 2D program based the finite element method. The analysis was done by varying of two condition, they are installation of sheet pile wall under the embankment and the sheet pile wall outside embankment. Sheet pile wall installation is carried out before embankment construction and length of sheet pile wall in this model is $15 \mathrm{~m}$. The soil layers beneath the embankment consist of $10 \mathrm{~m}$ layer of soft clay layer and $5 \mathrm{~m}$ of sand layer. The height of embankment in this analysis is $8 \mathrm{~m}$, where the constructing of the embankment was done in stages. The distance of sheet pile wall position under embankment from toe of embankment are $-9 \mathrm{~m},-6 \mathrm{~m},-3 \mathrm{~m}, 0 \mathrm{~m}$, $3 \mathrm{~m}$ dan $6 \mathrm{~m}$. The results of analysis show the effective position for displacement are toe of embankment. The Installation of sheet pile walls below the embankment will reducing deformation up to $78 \%$ and the safety factor will increase up to $10 \%$.
\end{abstract}

Keywords: Settelment, soft clay, sheet pile wall dan lateral deformation

\begin{abstract}
Abstrak
Timbunan di atas tanah lempung lunak dapat mempengaruhi penurunan pada tanah dasar, menimbulkan deformasi lateral dan vertikal di sekitar timbunan. Oleh karena itu, untuk mencegah terjadinya pengaruh timbunan diatas tanah lunak, maka dibutuhkan suatu perkuatan. Penelitian ini dilakukan untuk mengetahui pengaruh dinding turap sebagai salah satu perkuatan timbunan dengan menggunakan program PLAXIS 2D yang berbasis metode elemen hingga. Analisis dilakukan dengan memvariasikan dua posisi dinding turap yaitu dinding turap di bawah timbunan dan dinding turap di luar timbunan. Dinding turap dipasang sebelum dilakukan penimbunan dan panjang turap pada setiap pemodelan yaitu $15 \mathrm{~m}$. Lapisan tanah di bawah timbunan terdiri dari lapisan lempung lunak setebal $10 \mathrm{~m}$ dan lapisan pasir setebal $5 \mathrm{~m}$. Tinggi timbunan yang dimodelkan yaitu $8 \mathrm{~m}$ dimana penimbunannya dilakukan secara bertahap. Jarak dinding turap diposisikan terhadap kaki timbunan yaitu $-9 \mathrm{~m},-6 \mathrm{~m},-3 \mathrm{~m}, 0 \mathrm{~m}, 3 \mathrm{~m}$ dan $6 \mathrm{~m}$. Hasil dari analisis yang telah dilakukan, menunjukkan bahwa dinding turap pada posisi tepat pada kaki timbunan merupakan posisi dinding turap paling efektif. Dinding turap tepat di kaki timbunan menghasilkan reduksi deformasi di sekitar timbunan hungga $78 \%$ dan faktor keamanan meningkat sebesar $10 \%$.
\end{abstract}

Kata kunci: Penurunan, lempung lunak, dinding turap dan deformasi lateral

\section{Pendahuluan}

Tanah lempung lunak memiliki karakteristik khusus diantaranya yaitu bersifat kohesif, daya dukung relatif rendah, penurunan yang relatif besar, waktu pemampatannya yang lama, indek plastisitas yang tinggi, kadar air yang relatif tinggi, gaya geser yang kecil, permeabilitas yang rendah dan potensi kembang susut. Oleh karena itu, apabila tanah tersebut sebagai dasar konstruksi akan menimbulkan permasalahan. Salah satu permasalahan yang sering ditemukan pada 
konstruksi geoteknik yaitu tanah lempung lunak sebagai dasar timbunan.

Tanah lempung lunak sebagai dasar timbunan dapat mengakibatkan adanya penurunan pada tanah dasar, deformasi lateral dan vertikal di sekitar timbunan tersebut yang ditunjukkan pada Gambar 1a. Tanah lempung lunak dapat digunakan sebagai dasar timbunan apabila tanah lempung lunak tersebut telah dilakukan perbaikan ataupun digunakan penambahan struktur maupun non skruktur sebagai perbaikan tanah. Perbaikan tanah untuk mencegah deformasi dari tanah lempung lunak di bawah timbunan yang ditunjukkan pada Gambar 1b, solusi lainnya yaitu dengan pemasangan dinding turap baja sebagai perkuatan tanah. Dinding turap dapat memotong pengaruh di sekitar tanah akibat timbunan dapat ditunjukkan pada Gambar 1c (Harata et al., 2009).

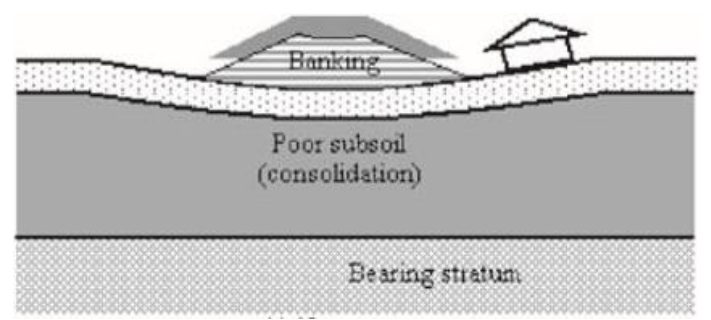

a. Penurunan tanpa perbaikan

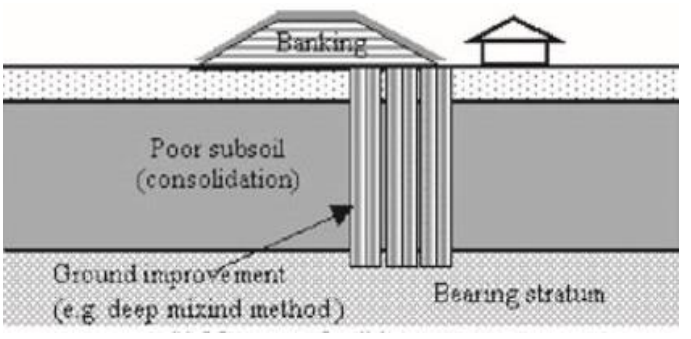

b. Penurunan dengan perbaikan tanah

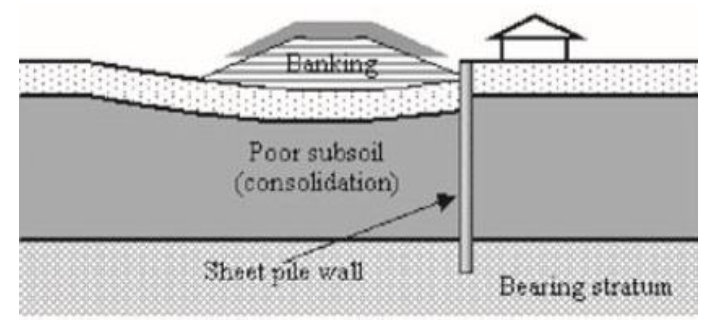

c. Penurunan dengan dinding turap

Gambar 1. Kondisi penanggulangan pada tanah lempung lunak (Harata et al., 2009)

Dinding turap merupakan dinding struktur vertikal yang memiliki ketebalan yang relatif tipis. Fungsi utama dari dinding turap yaitu sebagai dinding penahan tanah dimana dalam pemasangan dinding turap relatif murah dan mudah dalam pemasangan dinding turap.
Proses tahapan pembebanan dengan timbunan dapat dilakukan dengan satu tahap (single stage) atau dengan beberapa tahap (multi-stage loading). Pada tahap pembebanan timbunan dengan satu tahap akan mengurangi tekanan total dan penimbunan yang sangat cepat mengakibatkan tekanan air pori tidak dapat terdisipasi. Stabilitas timbunan ini akan tergantung pada kekuatan geser undrained $\left(\mathrm{s}_{\mathrm{u}}\right)$. Pembebanan dengan beberapa tahap pada tanah lempung lunak dapat meningkatan kekuatan tanah di bawah timbunan.

Hal ini disebabkan tanah di bawah timbunan tersebut dapat terkonsolidasi akibat beban atau timbunan diatasnya sehingga terjadi kenaikan kekuatan pada tanah tersebut. Namun, metode ini waktu konstruksi yang dibutuhkan akan cukup lama. Kriteria keruntuhan timbunan di atas tanah lunak terdapat 3 macam keruntuhan utama yang perlu diperhitungkan yaitu stabilitas daya dukung, stabilitas rotasi dan pergeseran horizontal dapat dilihat pada Gambar 2.

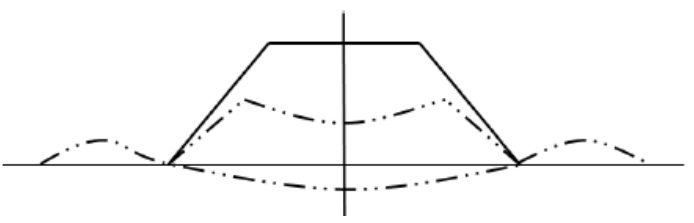

Keruntuhan daya dukung

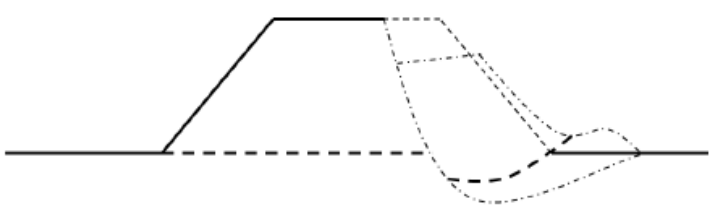

Keruntuhan rotasional

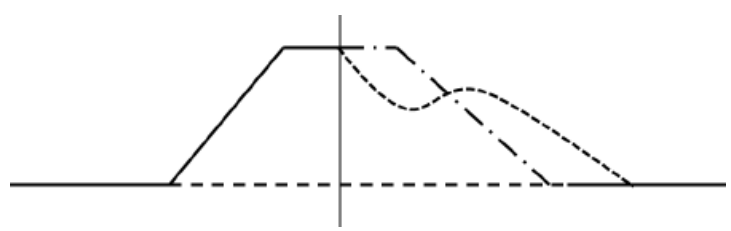

Keruntuhan lereng akibat pergeseran horisontal

Gambar 2 Tipe keruntuhan timbunan di atas tanah lunak (Manggada et al.,2015)

Hal yang penting dalam analisis stabilitas timbunan yaitu mempertimbangkan keruntuhan yang akan terjadi, terdapat dua keruntuhan yang terjadi yaitu circular and non-circular (Tan, 2005) yang dapat dilihat pada Gambar 3. Keruntuhan circular tidak menghasilkan fakor keamanan terkecil, seperti pada timbunan diatas tanah lunak yang tipis. Namun pada kegagalan yang terjadi umumnya pada kegagalan translasi. 
Tanah lempung lunak apabila mengalami pembebanan di atasnya akan mengakibatkan kenaikan tegangan. Kenaikan tegangan ini dapat mengakibatkan terjadinya penurunan pada tanah dasar. Penurunan terjadi pada tanah lunak yang terletak dibawah muka air tanah akibat adanya beban tambahan.

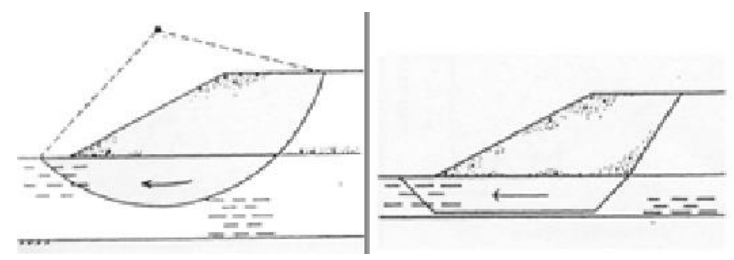

Gambar 3. Keruntuhan circular \& Non-Circular (Tan, 2005)

Dinding turap merupakan salah satu solusi yang dapat dilakukan untuk mereduksi tegangan yang terjadi akibat timbunan. Hal ini diakibat tegangan dapat terpotong oleh dinding turap. Sehingga dinding turap tersebut dapat mengurangi deformasi vertikal dan lateral akibat pengaruh tanggul pada yang terjadi di sekitar tanah (Harata et al., 2009). Dinding turap dapat mengurangi biaya konstruksi terutama pada lapisan lempung yang tebal dan efektif apabila memiliki ruang yang kecil agar struktur di sekitar timbunan tidak terganggu (Harata et al., 2009).

Dinding turap di tanah lempung lunak didesain untuk menjamin stabilitas timbunan dan struktur di sekitar tanggul pada tahapan timbunan. Efek utama yang diharapkan yaitu dinding turap dapat mereduksi deformasi vertikal, maka terjadi keseimbangan gaya vertikal. Salah satu aplikasi dinding turap pada tanah lunak di bawah kaki timbunan dapat dilihat pada Gambar 4.

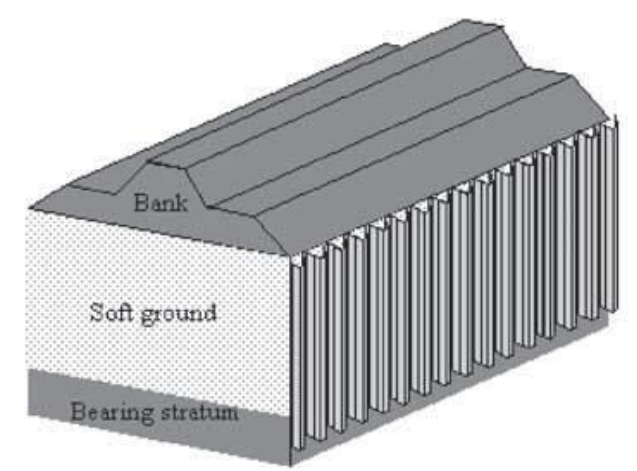

\section{Gambar 4 Dinding turap pada tanah lunak di bawah timbunan (Harata et al., 2009)}

Dalam menganalisis stabilitas dinding turap, teori keruntuhan diberlakukan. Teori keruntuhan merupakan keruntuhan pada suatu material dari hubungan antara tegangan normal dan geser (Mohr, 1900). Garis keruntuhan mengikuti bentuk lengkungnya, namun untuk sebagian besar masalahmasalah mekanika kekuatan material, garis tersebut didekati dengan garis lurus yang menunjukan hubungan linier antara tegangan normal dan geser (Coulomb, 1776). Adapun dua buah parameter yang digunakan pada Mohr Coulomb yaitu sudut geser $(\phi)$ dan kohesi (c) yang muncul dalam fungsi leleh dari model plastis.

Maksud penelitian ini adalah melakukan analisis pengaruh yang terjadi akibat pemasang dinding turap dan memvariasikan posisi dinding turap di bawah timbunan pada tanah lempung sehingga mendapatkan posisi dinding turap yang efektif. Sedangkan tujuan penelitian ini adalah untuk mengetahui pengaruh dinding turap, posisi efektif dinding turap dan mengetahui nilai faktor keamanan penggunaan dinding turap akibat adanya timbunan yang dapat mengakibatkan terjadinya deformasi vertikal dan lateral di sekitar timbunan.

\section{Metode}

Metode analisis yang dilakukan menggunakan metode elemen hingga (finite element method) yang dibantu dengan program PLAXIS 2D. Dalam menganalisis menggunakan PLAXIS 2D langkah yang harus dilakukan yaitu penentuan model geometri, model material, penentuan parameter model dan melakukan perhitungan. Geometri pada pemodelan dibagi menjadi elemen-elemen yang disebut sebagai jaringan elemen hingga. Setiap elemen memuat sejumlah titik nodal yang mempunyai sejumlah derajat kebebasan yang berkaitan dengan nilai dari parameter yang tidak diketahui dalam permasalahan nilai batas yang akan diselesaikan. Metode elemen hingga dalam PLAXIS 2D digunakan untuk menanalisis suatu keruntuhan tanah, faktor keamanan dengan mengurangi nilai kohesi dengan sudut geser. PLAXIS 2D dalam menganalisis dengan 2 kondisi pemodelan yaitu kondisi plane-strain maupun axisymmetric seperti Gambar 5.

Plane-strain digunakan dalam menganalisis model yang memiliki potongan melintang dan kondisi tegangan yang seragam. Sedangakan axisymmetric digunakan dalam menganalisis struktur atau pemodelan lingkaran yang memiliki potongan radial dan pembebanan seragam terhadap pusat dengan deformasi dan tegangan yang diaganggap bernilai sama pada arah radialnya.

Menurut Schweiger (2009) PLAXIS merupakan perangkat lunak yang berbasis elemen hinga dalam menganalisis dan mendesign bidang geoteknik. Model konstitutif yang digunakan sejalan dengan model linier elastis dan non-linier sampai model hardening double surface plasticity. 


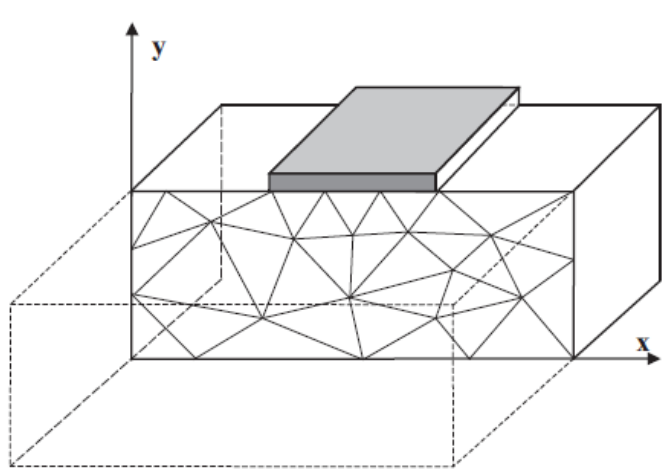

Plane-Strain

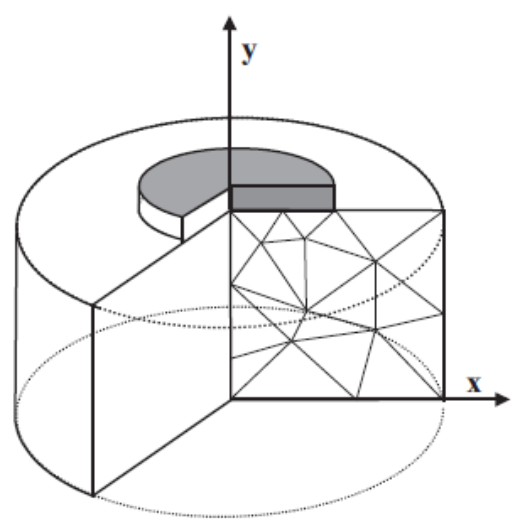

Axisymetric

\section{Gambar 5 Contoh pemodelan plane-strain dan} axisymetric (Brinkgreve et al., 2016)

Model hardening soil memiliki karakteristik umum yaitu tegangan tergantung pada kekakuan, geser hardening bersifat isotropik, kondisi kegagalan Mohr Coulomb, tidak terkait dengan plastic flow dan adanya cap hardening. Model hardening soil merupakan kelanjutan dari pemodelan MohrCoulomb dimana pada model hardening soil memperhitungkan tekanan pra-konsolidasi. Pemodelan menggunakan hardening soil merupakan model hiperbolik yang bersifat elastoplastis. Model hardening soil pertama kali diformulasikan oleh Kondner (1963) dan digunakan dalam model hiperbolik (Duncan et al., 1970).

Hardening dibagi menjadi dua jenis yaitu hardening geser dan hardening kompresi. Hardening geser digunakan untuk memodelkan regangan yang tidak dapat kembali seperti semula akibat tegangan deviator. Sedangkan, hardening kompresi diakibatkan oleh kompresi primer pada pembebanan satu arah dan pembebanan isotropis. Model ini merupakan model hardening yang tidak mengikutsertakan pelunakan tanah akibat dilatansi dan efek lepasnya ikatan anatar butir.
Menurut Duncan et al (1970), pemodelan hiperbolik digunakan untuk menentukan hubungan antara tegangan-regangan. Pada Gambar 6 menjelaskan hubungan antara tegangan dan regangan pada primary loading. Menurut Schanz et al (1998) model hardening soil merupakan model tingkat lanjut untuk memodelkan perilaku dari berbagai jenis tanah, baik untuk tanah lunak maupun tanah yang keras. Secara rinci, perumusan dan verifikasi terdapat hardening soil model terdapat 10 Parameter yang digunakan dalam Hardening Soil, seperti yang ditunjukan pada Tabel 1.

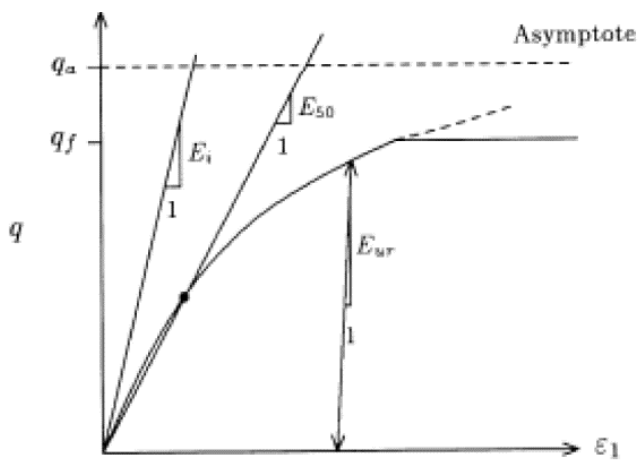

Gambar 6. Hubungan tegangan-regangan hiperbolik pada pembebanan utama untuk uji triaksial terdrainase standar

(Schanz et al., 1998)

Tabel 1. Parameter pada pemodelan hardening soil (Schanz et al., 1999)

\begin{tabular}{cl}
\hline Parameter & \multicolumn{1}{c}{ Deskripsi } \\
\hline$\phi^{\prime}$ & Sudut geser dalam \\
$\mathrm{c}^{\prime}$ & Kohesi \\
$R f$ & Rasio keruntuhan \\
$\psi$ & Sudut dilantasi \\
$E_{50}^{\text {ref }}$ & Kekakuan sekan dari uji triaksial \\
terdrainase \\
$E_{\text {oef }}^{\text {ref }}$ & Kekakuan tangensial untuk \\
$E_{u r}^{r e f}$ & pembebanan primer \\
$\mathrm{m}$ & Kekakuan untuk \\
& Eksponen ketergantungan terhadap \\
& tegangan \\
$v_{u r}$ & Angka poisson untuk \\
& pengurangan/pembebanan kembali \\
$K_{O}^{n c}$ & Nilai K0 untuk tanah \\
& terkonsolidasi normal \\
\hline
\end{tabular}

Penggunaan hardening soil sebagai model material pada PLAXIS 2D umumnya menghasilkan waktu perhitungan yang lebih lama, karena pembentukan dan dekomposisi kekakuan dari material dilakukan dalam tiap langkah perhitungan. Bidang keruntuhan pemodelan hardening soil pada ruang tiga dimensi ditunjukkan pada Gambar 7. 
Tabel 2. Parameter tanah pada pemodelan

\begin{tabular}{|c|c|c|c|c|c|c|c|c|c|c|c|c|}
\hline \multirow{2}{*}{ Lap. } & \multirow{2}{*}{ Jenis tanah } & $\begin{array}{c}\text { Kedala- } \\
\text { man }\end{array}$ & Yunsat & Ysat & $E_{50}{ }^{r e f}$ & Eoed $^{\text {ref }}$ & $E_{u r}{ }^{r e f}$ & $\mathbf{m}$ & $\mathbf{c}^{\prime}$ ref & $\begin{array}{c}\phi^{\prime} \\
\text { (phi) }\end{array}$ & $\psi(\mathrm{psi})$ & $\mathbf{k}_{\mathrm{x}}=\mathbf{k}_{\mathbf{y}}$ \\
\hline & & $\mathbf{m}$ & $\begin{array}{l}\mathbf{k N} / \\
\mathbf{m}^{3}\end{array}$ & $\mathrm{kN} / \mathrm{m}^{3}$ & $\begin{array}{l}\mathbf{k N} / \\
\mathbf{m}^{2}\end{array}$ & $\begin{array}{l}\mathbf{k N} / \\
\mathbf{m}^{2}\end{array}$ & $\begin{array}{l}\mathbf{k N} / \\
\mathbf{m}^{2}\end{array}$ & $\mathbf{m}$ & $\mathrm{kN} / \mathrm{m}^{2}$ & $\mathbf{o}$ & o & m/day \\
\hline 1 & $\begin{array}{l}\text { Lempung } \\
\text { lunak }\end{array}$ & $0 \mathrm{~s} / \mathrm{d} 10$ & 15 & 16 & 7.000 & 4.500 & 25.000 & 1 & 15 & 22,5 & 0 & $7 \times 10^{-5}$ \\
\hline \multirow[t]{3}{*}{2} & Pasir & $10 \mathrm{~s} / \mathrm{d} 40$ & 19 & 20 & 40.000 & 40.000 & 120.000 & 0,65 & 0,1 & 27,5 & 2 & 7,128 \\
\hline & $\begin{array}{l}\text { Timb } \\
\text { lempung }\end{array}$ & $8 \mathrm{~s} / \mathrm{d} 0$ & 17 & 18 & 30.000 & 30.000 & 95.000 & 0,5 & 10 & 35 & 0 & 0,04752 \\
\hline & & & & & & $\begin{array}{l}-\mathrm{EA} \\
-\mathrm{EI} \\
-\mathrm{w} \\
-\mathrm{v}(\mathrm{n}\end{array}$ & \multicolumn{4}{|c|}{$\begin{array}{l}=6,43 \times 10^{6} \mathrm{kN} / \mathrm{m} \\
=1,81 \times 105 \mathrm{kN} / \mathrm{m} \\
=1,805 \mathrm{kN} / \mathrm{m} / \mathrm{m} \\
=0,15\end{array}$} & & \\
\hline
\end{tabular}

Pemodelan dinding turap dimodelkan pada program plaxis sebagai elemen pelat dan antarmuka (interface). Perilaku elemen pelat dapat dibedakan antara perilaku elastis dan elastoplastis. Antarmuka (interface) pada pelat merupakan pemodelan interaksi antar dinding turap dan tanah. Tingkat interaksi dimodelkan dengan menggunakan nilai tertentu untuk faktor reduksi kekuatan $\left(R_{\text {inter }}\right)$ pada elemen. Faktor reduksi kekuatan $\left(R_{\text {inter }}\right)$ pada pemodelan diasumsikan bernilai 0,667 . tanah lempung lunak dan pasir. Kondisi muka air tanah terletak pada kedalaman $1 \mathrm{~m}$ dan panjang dinding turap $15 \mathrm{~m}$, seperti yang ditunjukan pada Gambar 8.

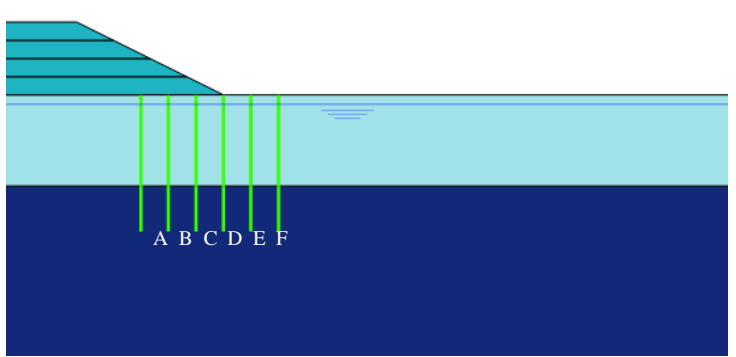

Gambar 8. Geometri pada pemodelan PLAXIS 2D

Kemiringan timbunan yang digunakan untuk pemodelan ini adalah $1 \mathrm{~V}: 2 \mathrm{H}$ dengan ketinggian timbunan $8 \mathrm{~m}$. Tahap konstruksi timbunan yaitu dengan metode pembebanan dengan beberapa tahap. Tahap timbunan dibagi menjadi empat tahap lapisan, pada setiap lapisan dengan ketinggian dua meter. Parameter tanah yang digunakan dalam analisis merupakan parameter yang didapatkan dari beberapa literatur yang mendeskripsikan jenis tanah dan sifat fisik yang sesuai. Detail parameter pada pemodelan tanah dapat dilihat pada Tabel 2.

Parameter dinding turap yang digunakan, merupakan material baja. Parameter yang didapatkan dari beberapa literatur dengan type $U$-shape $500 \times 225 \times 27,5$, yaitu sebagai berikut:
Pemodelan dinding turap dilakukan untuk mengatahui pengaruh dinding turap yang ditimbulkan akibat beban atau timbunan pada tanah lunak dengan memvariasikan posisi dinding turap seperti pada Gambar 9 dan Tabel 3. Pada analisis ini melakukan analisis deformasi plastik-elastis akibat adanya pemasangan dinding turap. Namun, pada kondisi ini tidak terjadinya perubahan tekanan air pori berlebih.

Tabel 3. Jarak dinding turap dari kaki timbunan

\begin{tabular}{cc}
\hline Dinding turap & Jarak (m) \\
\hline TRP A & -9 \\
TRP B & -6 \\
TRP C & -3 \\
TRP D & 0 \\
TRP E & +3 \\
TRP F & +6 \\
\hline
\end{tabular}

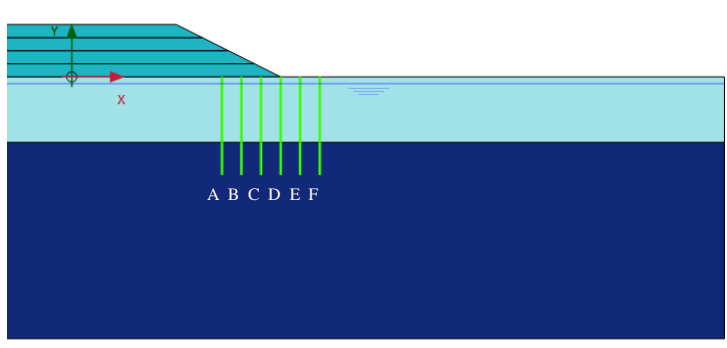

Gambar 9. Pemodelan penempatan variasi dinding turap 
Mesh adalah proses pembagian stuktur menjadi elemen-elemen dan titik-titik nodal elemen. Tujuan mesh pada pemodelan yaitu untuk melakukan perhitungan setiap jaring dalam metode elemen hingga. Jaring terdiri dari elemen-elemen yang dihubungkan dengan nodal dimana nilai dari variable dapat dihitung pada nodal tersebut. Jenis mesh dapat mempengaruhi ketelitian dan waktu yang dibutuhkan untuk menganalisis.

Apabila jenis mesh semakin baik, maka tingkat ketelitian semakin baik namun waktu yang dibutuhkan untuk mengkalkulasi akan semakin lama. Jenis mesh pada analisis pemodelan ini menggunakan jenis mesh fine ditunjukan pada Gambar 10.

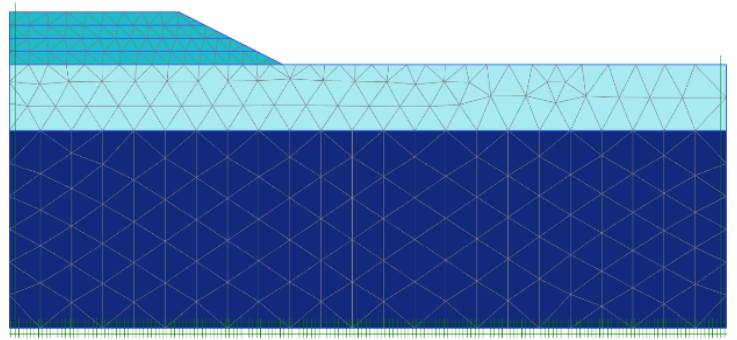

Tanpa adanya dinding turap

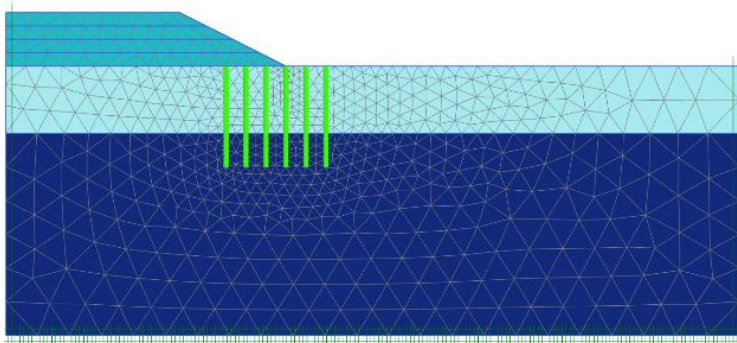

Adanya dinding turap

\section{Gambar 10. Jaring -jaring elemen pada pemodelan menggunakan PLAXIS 2D}

Pada tahap awal analisis melakukan perhitungan untuk menentukan tegangan awal. Kondisi tegangan ini umumnya dinyatakan oleh tegangan vertikal efektif awal dan tegangan horizontal efektif awal. Tegangan horizontal efektif awal $\left(\sigma_{h o}^{\prime}\right)$ merupakan hubungan dengan koefisien tekanan tanah lateral $\left(k_{0}\right)$ dengan tegangan vertikal efektif awal $\left(\sigma_{v o}^{\prime}\right)$, sehingga tegangan horizontal dapat ditulis perti pada Persamaan 1.

$\sigma_{\text {ho }}^{\prime}=k_{0} \cdot \sigma_{v o}^{\prime}$

dimana $\sigma_{v o}^{\prime}$ merupakan tegangan efektif vertikal awal, $\sigma_{h o}^{\prime}$ merupakan kegangan efektif horizontal awal, $k_{0}$ merupakan koefisien tanah saat diam dam Nilai $k_{0}$ dapat dicari dengan Persamaan 2, dengan $\phi$ merupakan sudut geser $\left(^{\circ}\right)$. $k_{0}=1-\sin \varnothing$

Teori Biot (Biot, 1956) merupakan teori yang digunakan dalam mengkalkulasi konsolidasi dalam program PLAXIS 2D. Menurut prinsip dari Terzaghi, tegangan dibedakan menjadi tegangan efektif dan tekanan air pori:

$\underline{\sigma}=\underline{\sigma^{\prime}}+\underline{m}\left(p_{\text {stabil }}+p_{\text {berlebih }}\right)$

Dimana $\underline{\sigma}$ merupakan vektor tegangan total, $\sigma^{\prime}$ merupakan tegangan efektif, $p_{\text {berlebih }}$ merupakan tekanan air pori berlebih, $p_{\text {stabil }}$ merupakan solusi statis pada akhir dari proses konsolidasi, dan $\underline{m}$ merupakan vektor yang berisi nilai satu untuk komponen tegangan normal dan nol untuk komponen tegangan geser.

Di dalam PLAXIS 2D $P_{\text {stabil }}$ didefenisikan sebagai (Persamaan 4)

$P_{\text {stabil }}=\sum M_{\text {weight }} \cdot p_{\text {masukan }}$

Dimana $p_{\text {masukan }}$ merupakan tekanan air pori yang dihitung dalam program masukan atau berdasarkan perhitungan aliran air tanah. Pada Program PLAXIS 2D tegangan bersifat kompresif atau tekanan dianggap negatif dan berlaku juga terhadap tegangan efektif maupun tekanan air pori. Konsolidasi digunakan untuk menganalisis disipasi tekanan air pori berlebih dalam tanah lunak yang jenuh air sebagai fungsi waktu. Analisis konsolidasi dalam PLAXIS 2D dapat dilakukan bersamaan dengan tahapan konstruksi, seperti tahapan lapisan timbunan.

Analisis keamanan dengan mereduksi parameter tanah dalam program PLAXIS 2D disebut reduksi phi-c. Proses ini akan berakhir pada suatu kondisi keruntuhan. Oleh karena itu, tahapan reduksi phi-c tidak dapat menjadi kondisi awal untuk tahapan perhitungan yang lainnya. Pada analisis perhitungan dilakukan setelah tahapan konstruksi selesai yaitu setelah tahapan timbunan terakhir. Karena faktor keamanan saat kodisi kritis pada timbunan yaitu pada konstruksi selesai (end construction).

Saat menggunakan kombinasi reduksi phi-c dengan hardening soil model maka akan berperilaku secara pemodel Mohr Coulomb standar, karena sifat kekakuan yang tergantung dari tegangan serta efek hardening tidak diperhitungkan. Oleh karena itu, kekakuan yang digunakan adalah kekakuan yang dihitung pada awal tahapan perhitungan dan tetap bernilai konstan hingga tahapan perhitungan selesai. Modulus kekakuan yang bergantung pada tegangan akhir dari perhitungan sebelumnya digunakan sebagai modulus kekakuan yang konstan dalam perhitungan reduksi phi-c. Reduksi phi-c pada PLAXIS 2D merupakan metode perhitungan yang dasarnya pada faktor keamanan konvensional yang 
digunakan dalam analisis lingkaran gelincir. Reduksi phi-c menggunakan parameter kekuatan $\tan \phi$ dan $c$ dari tanah selanjutnya akan direduksi hingga pemodelan hingga terjadi keruntuhan. Oleh karena itu kekuatan pada struktural tidak dipengaruhi oleh reduksi phi-c. Mendapatkan nilai faktor kemanan dalam didefinisikan sebagai berikut:

$\sum M s f=\frac{\tan \emptyset_{\text {available }}}{\tan \emptyset_{\text {failure }}}=\frac{C_{\text {available }}}{C_{\text {failure }}}$

Dimana tan $\emptyset_{\text {available }}$ merupakan sudut geser dalam tanah, $\tan \emptyset_{\text {failure }}$ merupakan Sudut geser dalam tereduksi, $c_{\text {available }}$ merupakan Kohesi tanah daam tanah dan $c_{\text {failure }}$ merupakan Kohesi tanah dalam tereduksi.

\section{Hasil dan Pembahasan}

Pemodelan dan kalkulasi telah dilakukan, maka didapatkan beberapa hasil yang didapatkan seperti penurunan, deformasi yang terjadi dan faktor keamanan. Hasil pemodelan awal yang dilakukan yaitu pemodelan tanpa adanya dinding turap, deformasi yang terjadi akibat timbunan di tanah lunak tersebut dapat dilihat pada Gambar 11. Pergerakan tanah yang terjadi akibat tanah timbunan akan secara horizontal dari beban timbunan dan vertikal kearah atas pada daerah sekitar timbunan.

Hal ini dikarenakan, Tanah lunak dibawah timbunan tertekan secara vertikal, mengakibatkan tanah berrotasi kearah luar timbunan dan mengangkat tanah kearah atas. Total Perpindahan yang terjadi akibat timbunan di tanah lunak tersebut dapat dilihat pada Gambar 12.

Total perpindahan yang terjadi pada tahap timbunan pertama dan kedua sangat kecil dibandingkan dengan tahap timbunan ketiga dan keempat seperti Gambar 12. Akibat timbunan mengakibatkan terjadinya perpindahan di sekitar timbunan. Hal ini diakibatkan berat timbunan menekan tanah dibawahnya dan tanah mendesak ke segala arah dan mengakibatkan adanya perpindahan di area sekitar timbunan.

Pengaruh timbunan pada tanah lempung lunak mengakibatkan adanya deformasi hingga $20 \mathrm{~m}$ dari jarak timbunan tersebut. Faktor keamanan, distribusi tegangan dan bidang keruntuhan yang terjadi dapat dilihat pada Gambar 13 .

Hasil analisis pada bidang longsor pada Gambar 13, dapat dilihat bahwa lapisan tanah yang berbatasan berada pada kedalaman yang lebih dalam. Nilai faktor keamanan tanpa perkuatan dengan dinding turap yaitu 1.090. Nilai keamanan tersebut dapat dikatakan bahwa kondisi tersebut tanah di bawah timbunan hampir tidak dapat menahan berat timbunan tersebut.
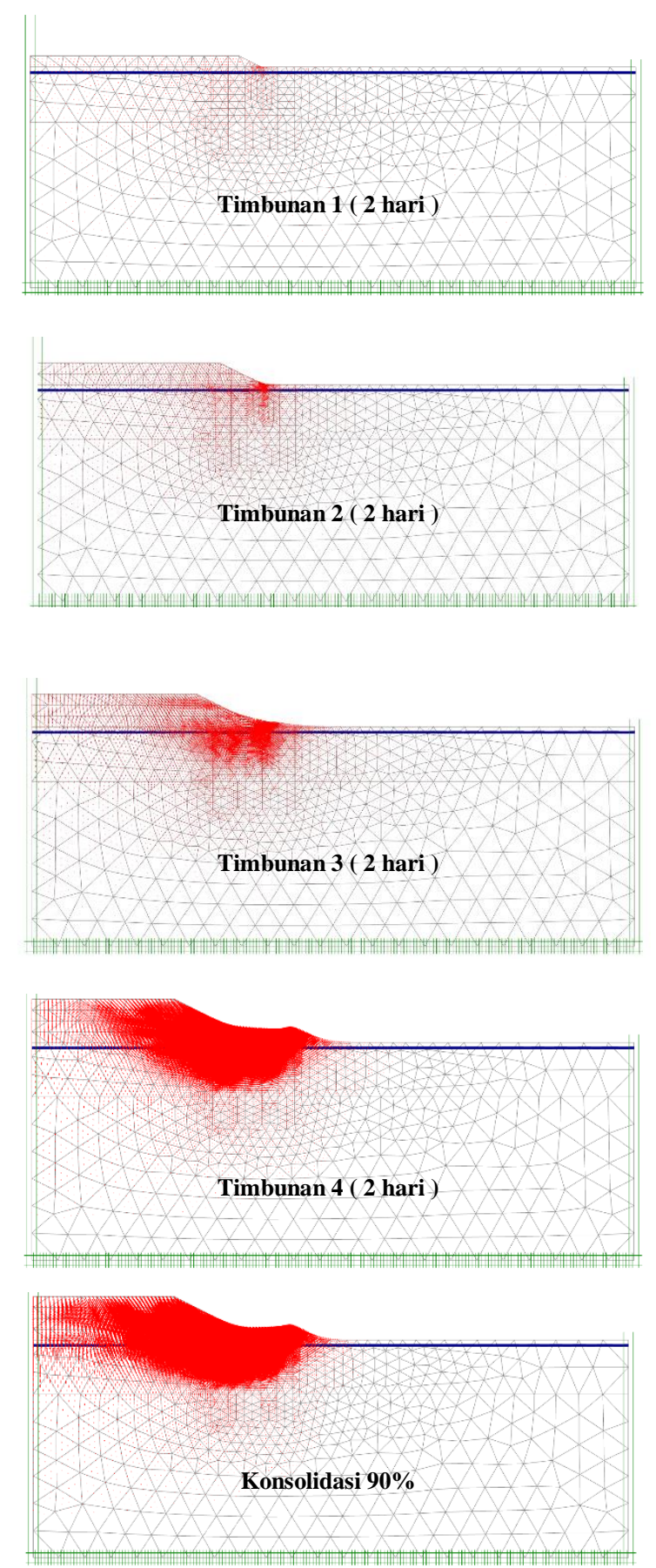

Gambar 11. Arah pergerakan dan deformasi yang terjadi akibat timbunan

Pemodelan selanjutnya yaitu pemodelan menggunakan perkuatan dengan dinding turap dengan mevariasi jarak mulai dari $-9 \mathrm{~m}$ sampai $3 \mathrm{~m}$ dari kaki timbunan. Pemodelan dilakukan dengan memvariasikan jarak posisi dinding dari kaki timbunan yaitu $-9 \mathrm{~m}$ (TRP A), -6 m (TRP B), $-3 \mathrm{~m}$ (TRP C), 0 m (TRP D), $3 \mathrm{~m}$ (TRP E) dan $6 \mathrm{~m}$ (TRP F). Hasil pemodelan tesebut, Perubahan total perpindahan yang terjadi pada setiap tahapan lapisan timbunan dan kosolidasi $90 \%$ dapat dilihat pada Gambar 14. 


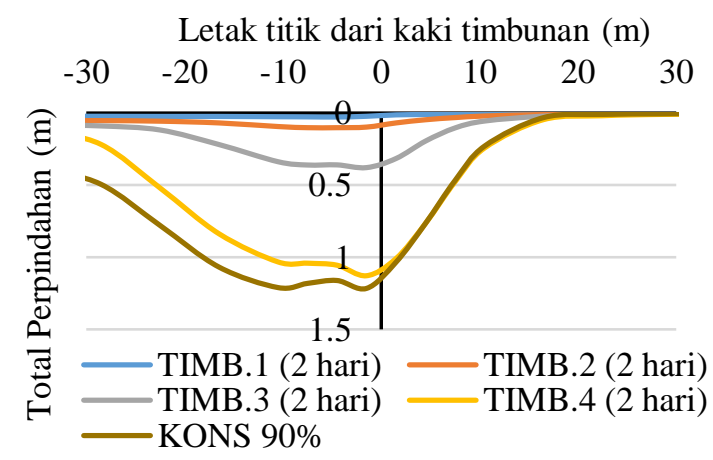

Gambar 12. Total perpindahan yang terjadi akibat timbunan pada tanah lunak

Letak titik dari kaki timbunan (m)

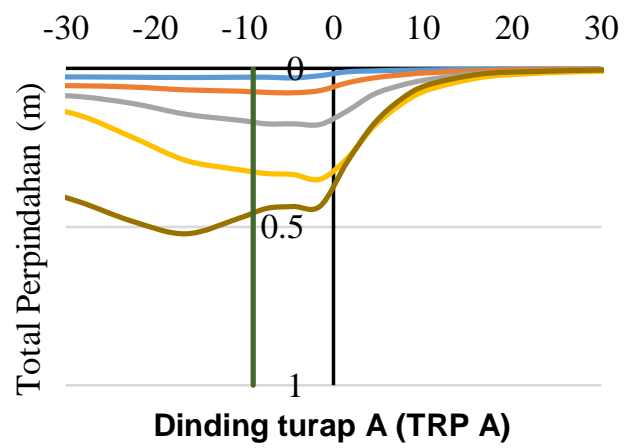

Letak titik dari kaki timbunan (m)

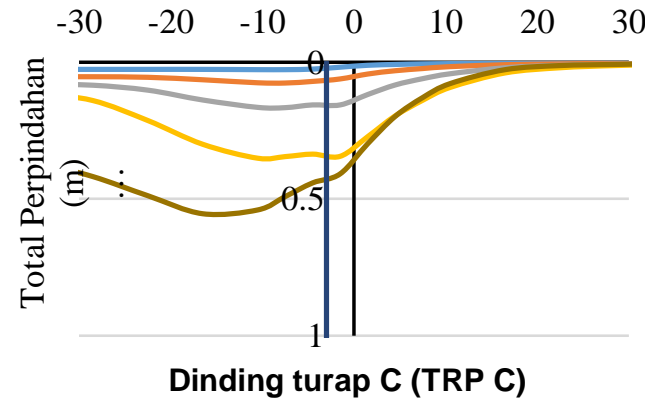

Letak titik dari kaki timbunan (m)

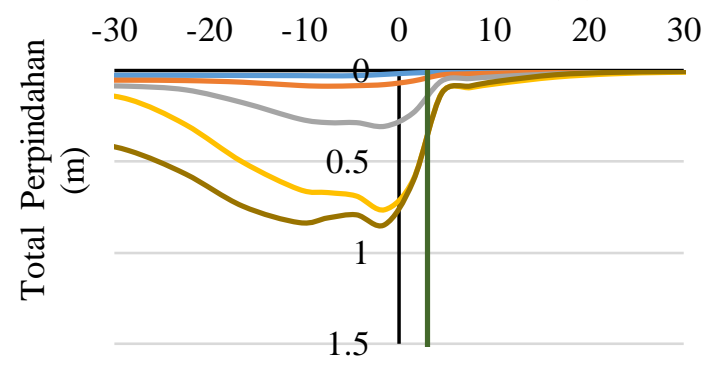

Dinding turap E (TRP E)

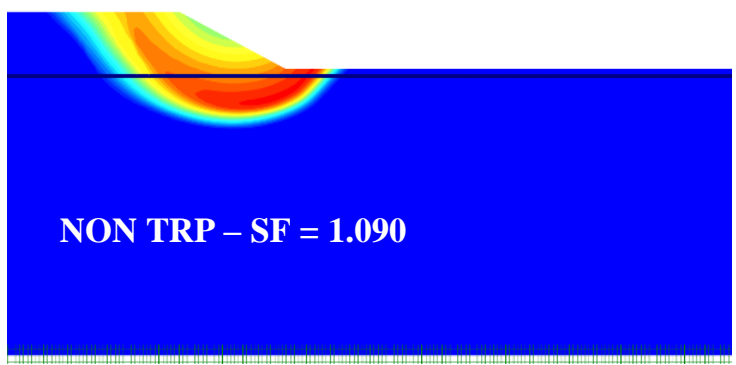

Gambar 13. Bidang keruntuhan yang terjadi pada pemodelan

Letak titik dari kaki timbunan (m)

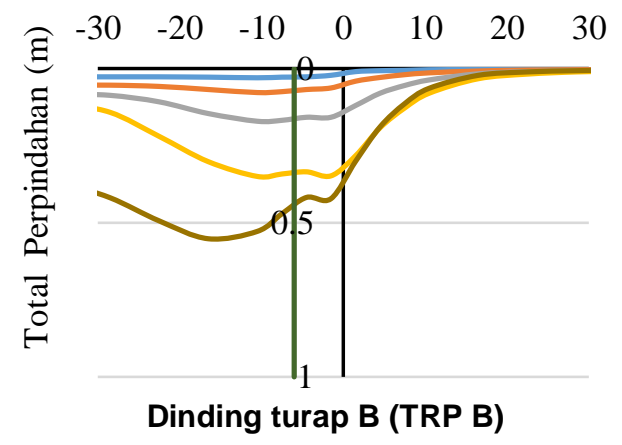

Letak titik dari kaki timbunan (m)

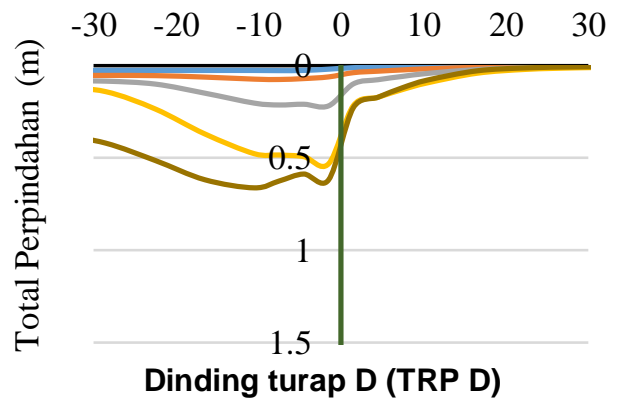

Letak titik dari kaki timbunan (m)

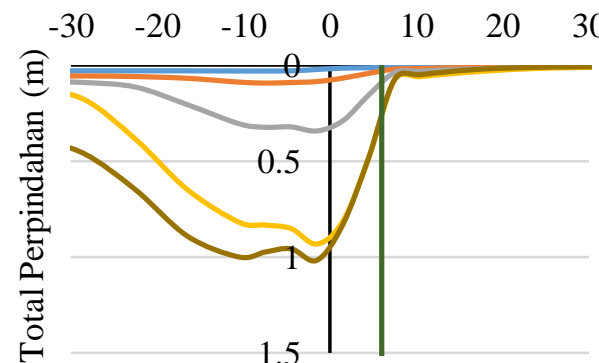

Dinding turap F (TRP F)

TIMB.1 (2 hari) — TIMB.2 (2 hari) —TIMB.3 (2 hari) — TIMB.4 (2 hari) - KONS 90\%

Gambar 14. Total perpindahan yang terjadi pada setiap tahapan konstruksi pada pemodelan menggunakan dinding turap 
Pada Gambar 12 dan 14 apabila dibandingkan kondisi tanpa dinding turap dan adanya dinding turap, Penurunan yang terjadi pada setiap lapisan timbunan cukup signifikan. Dinding turap dapat mereduksi penurunan yang terjadi akibat timbunan dan mereduksi perpindahan yang terjadi di luar timbunan. Pada Gambar 14 dapat dilihat, total perpindahan yang terjadi di sekitar timbunan dan di bawah timbunan pada pemodelan TRP A, TRP B, TRP C tidak terjadi perubahan yang signifikan. Sedangkan, pemodelan dinding turap diluar timbunan pada pemodelan TRP E dan TRP F total perpindahan yang terjadi di sekitar timbunan dapat tereduksi. Namun penurunan yang terjadi di bawah timbunan, semakin dinding turap menjahui timbunan maka total penurunan yang terjadi semakin besar.

Pada pemodelan dinding turap tepat di kaki timbunan yaitu TRP D dapat dilihat bahwa total perpindahan yang terjadi disekitar timbunan dan di bawah timbunan terreduksi. Hal ini dikarenakan posisi turap merupakan batas dari timbunan tersebut sehingga tanah yang mengalami perpindahan akibat timbunan dapat tertahan oleh dinding turap. Oleh karena itu, tanah di luar timbunan tidak terpegaruh oleh tekanan yang berotasi akibat timbunan. Arah perubahan perpindahan yang terjadi dinding turap dapat di lihat pada Gambar 15.

Perubahan deformasi yang terjadi akibat adanya perkuatan menggunakan dinding turap dibandingkan tanpa dinding turap seperti ditunjukan pada Gambar 15 , dinding turap dapat menahan deformasi yang

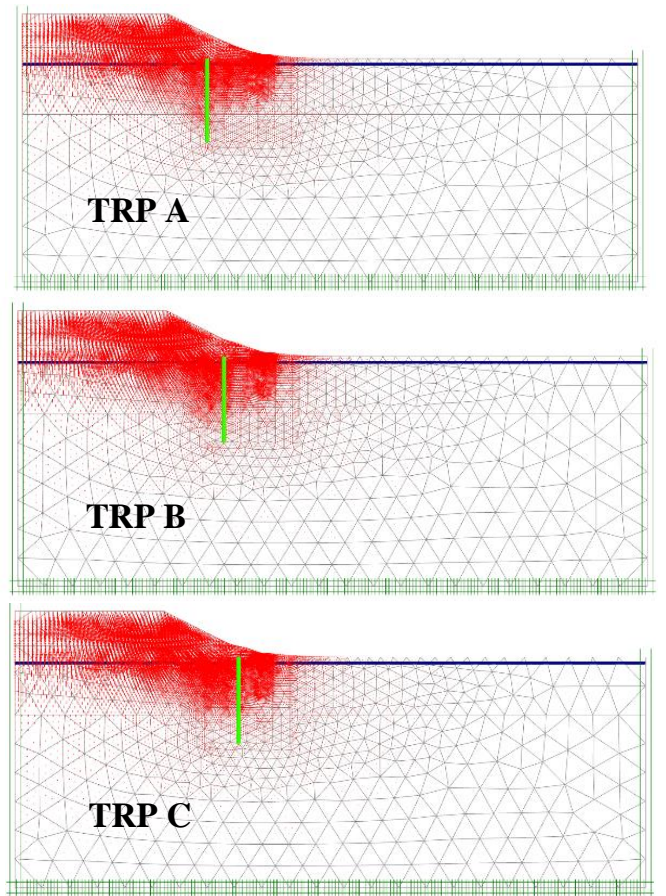

terjadi. Pada dinding turap dibawah timbunan dapat mereduksi adanya perubahan total perpindahan yang jadi, namun masih terjadi diluar sekitar timbunan. Sedangkan pada dinding turap terletak diluar timbunan tidak terjadi perubahan deformasi yang cukup signifikan namun deformasi yang terjadi di luar timbunan dapat mereduksi perubahan deformasi, dapat dilihat bidang longsor yang terjadi pada setiap pemodelan pada Gambar 16.

Pada Gambar 16, TRP A, TRP B, dan TRP C dapat dilihat bawah bidang longsor terbagi menjadi dua bagian. Hal ini diakibatkan pada kedua bagian tersebut masih menerima beban diatasnya. Nilai faktor keamanan pun meningkat, hal ini disebabkan karena nilai faktor keamanan yang terjadi berubah akibat dinding turap memotong bidang kelongsoran tersebut. Nilai faktor keamanan pada analisis TRP A, TRP B dan TRP C tidak berubah signifikan. Sedangkan analisis pada TRP E dan TRP F, semakin dinding turap menjahui timbunan bidang keruntuhan yang terjadi semakin menyurupai bidang keruntuhan tanpa dinding turap.

Hasil analisis pada pemodelan TRP D merupakan pemodelan dinding turap dengan posisi yang paling efektif, hal ini disebabkan pada bidang longsor akibat timbunan semua tertahan oleh dinding turap dan tegangan yang terjadi di sekitar timbunan dapat tereduksi yang dapat dilihat dari perubahan warna pada diagram tegangan. Perubahan total perpindahan yang terjadi di luar sekitar timbunan dari kaki timbunan dapat dilihat pada Gambar 17 dan Tabel 4.

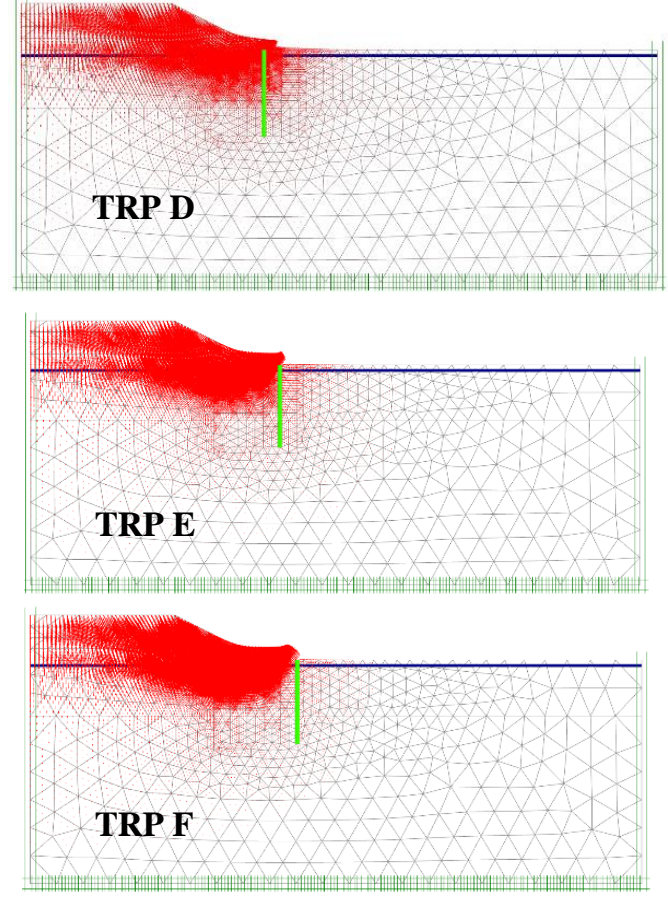

Gambar 15. Arah perubahan deformasi pada konsolidasi $90 \%$ 

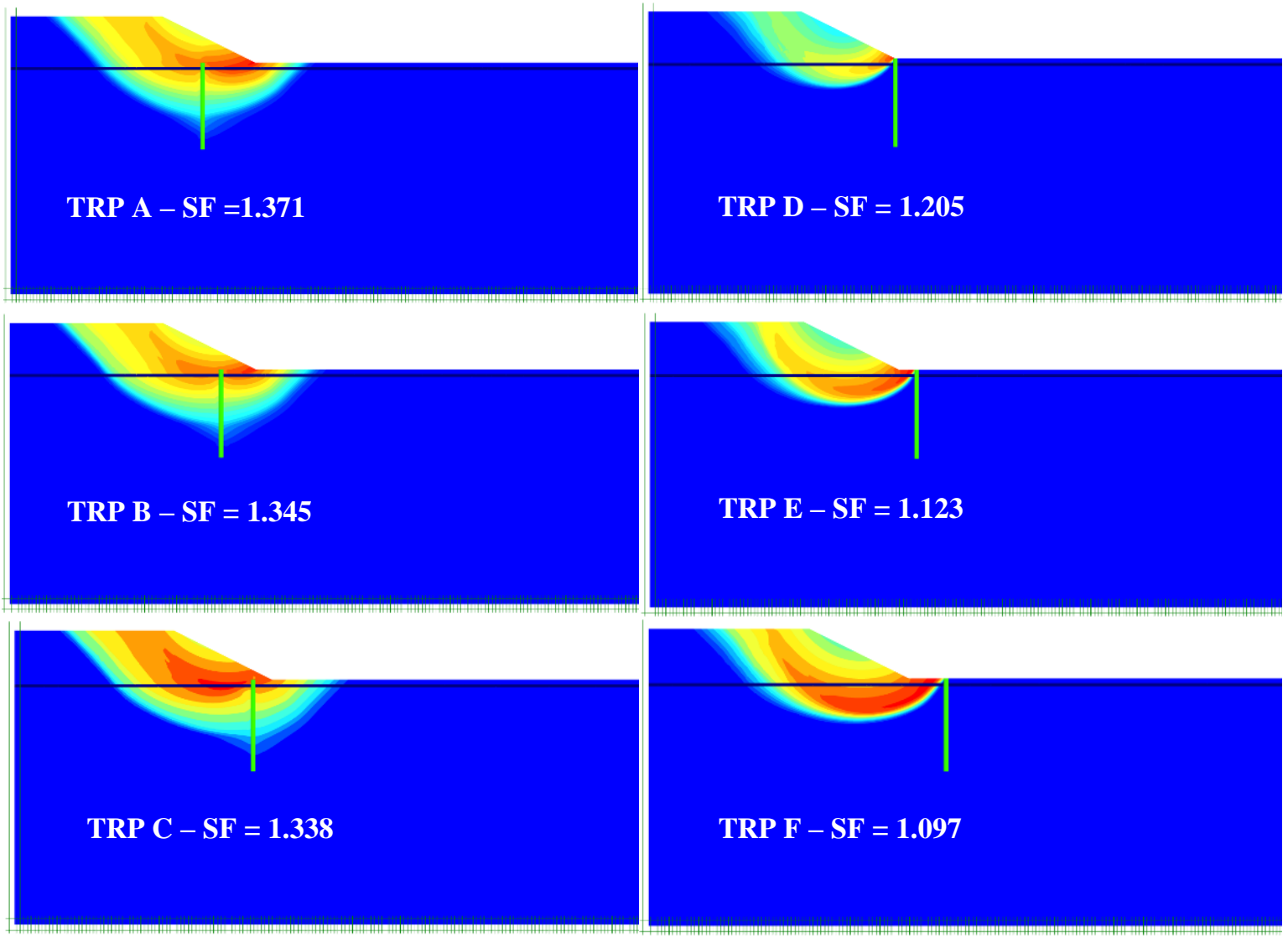

Gambar 16. Bidang keruntuhan yang terjadi pada pemodelan

Tabel 4. Persentase maksimum reduksi disekitar timbunan

\begin{tabular}{cccc}
\hline Kondisi & $\begin{array}{c}\text { Posisi } \\
\text { TRP }\end{array}$ & $\begin{array}{c}\text { Kons. } \\
\mathbf{9 0 \%} \\
(\mathbf{m})\end{array}$ & $\begin{array}{c}\text { \% Total } \\
\text { Perpindahan } \\
(\mathbf{\%})\end{array}$ \\
\hline Tanpa TRP & & 1,163 & 0 \\
TRP A & -9 & 0,397 & 65,87 \\
TRP B & -6 & 0,389 & 66,56 \\
TRP C & -3 & 0,391 & 66,39 \\
TRP D & 0 & 0,251 & 78,42 \\
TRP E & -3 & 0,777 & 33,20 \\
TRP F & -6 & 0,950 & 18,32 \\
\hline
\end{tabular}

Pada Gambar 17 dan Tabel 4 menunjukan bahwa dinding turap dapat mempengaruhi penurunan yang terjadi di bagian luar timbunan. Dari hasil analisis, pemodelan diluar timbunan tidak terjadi perubahan deformasi yang signifikan dibandingkan pemodelan tanpa dinding turap. Sedangkan pemodelan dibawah timbunan terjadi perubahan deformasi yang signifikan. Pemodelan TRP A, TRP B dan TRP C deformasi yang terjadi tidak signifikan.

Berbeda dengan pemodelan TRP D, deformasi yang terjadi merupakan pemodelan dengan reduksi paling besar yaitu $78 \%$ dimana dinding turap terletak tepat berada dibawah kaki timbunan. Faktor keamanan yang terjadi akibat pengaruh dinding turap dibandingkan tanpa dinding turap dapat dijelaskan pada Tabel 5.

Jarak dari kaki timbunan (m)

024681012141618202224262830

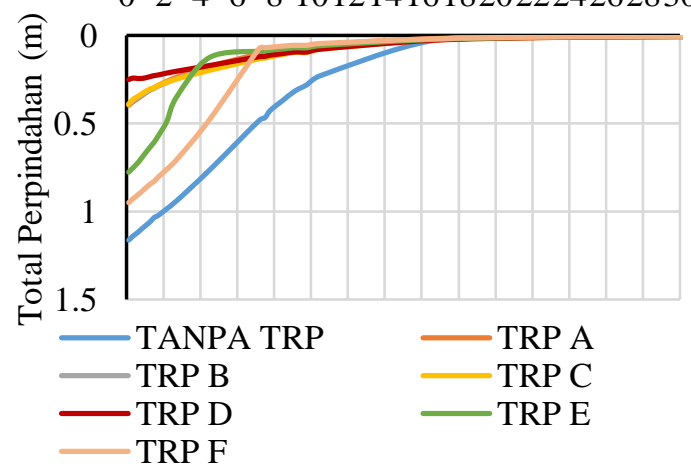

\section{Gambar 17. Deformasi pada bagian luar timbunan pada kosolidasi $90 \%$}

Posisi dinding turap pada tanah lunak di bawah timbunan mempengaruhi perubahan total perpindahan dan juga nilai faktor keamanan. Dinding turap di bawah timbunan dimana posisi dinding turap maksimum $9 \mathrm{~m}$ dapat menaikan faktor kemanan yaitu $25 \%$. Sedangkan, dinding turap diluar timbunan dimana posisi dinding turap maksimum 6 $\mathrm{m}$ dari kaki timbunan dapat menaikan faktor keamanan hingga $10 \%$. 
Tabel 5. Persentase kenaikan faktor keamanan pada dinding turap

\begin{tabular}{cccc}
\hline Kondisi & $\begin{array}{c}\text { Posisi } \\
\text { SPW }\end{array}$ & $\begin{array}{c}\text { Faktor } \\
\text { keamanan }\end{array}$ & $\begin{array}{c}\text { \% Kenaikan SF } \\
(\%)\end{array}$ \\
\hline Tanpa TRP & & 1,090 & 0 \\
TRP A & -9 & 1,371 & 25,780 \\
TRP B & -6 & 1,345 & 23,394 \\
TRP C & -3 & 1,338 & 22,752 \\
TRP D & 0 & 1,205 & 10,550 \\
TRP E & -3 & 1,123 & 3,028 \\
TRP F & -6 & 1,097 & 0,642 \\
\hline
\end{tabular}

\section{Kesimpulan}

Pemodelan yang dilakukan dengan menvariasi dua posisi dinding turap yaitu dibawah timbunan dan diluar timbunan dapat disimpulkan bawah dinding turap dapat mempengaruhi total penurunan, faktor keamanan maupun deformasi vertikal dan horizontal. Dinding turap dibawah timbunan dapat mereduksi perubahan total perpindahan yang terjadi di bawah timbunan dan meningkatkan nilai faktor keamanan. Namun perpindahan total disekitar timbunan tidak terjadi perubahan yang signifikan.

Hasil analisis dinding turap diluar timbunan berupa total perpindahan dan nilai faktor keamanan yang terjadi tidak signifikan dibandingkan dengan tanpa dinding turap. Semakin dinding turap diposisikan ketengah timbunan maka nilai faktor keamanan semakin meningkat. Hal ini disebabkan bidang keruntuhan yang terjadi dapat direduksi oleh dinding turap. Dan sebaliknya, semakin dinding turap di posisikan semakin menjauhi timbunan maka nilai faktor keamanan semakin menurun. Pada pemodelan dinding turap yang efektif yaitu posisi dinding turap tepat pada kaki timbunan atau pada pemodelan TRP $\mathrm{D}$, dimana pada pemodelan tersebut merupakan pemodelan dengan reduksi perpindahan di sekitar timbunan yaitu $78 \%$ dan faktor keamanan meningkat sebesar $10 \%$.

\section{Daftar Pustaka}

Biot, M. A. (1956). General Solution of The Equations of Elasticity and Consolidation for Porous Material. Journal of Applied Mechanics, 23(2).

Brinkgreve, R. B. J. Kumarswamy, S., Swolfs, W. M., Waterman, D., Chesaru, A., Bonnier, P. G., \& Haxaire, A. (2016). Reference manual, PLAXIS, Netherlands.
Coulomb, C. A. (1776). Essai sur une application des règles de maximis et minimis à quelques problemes de statique, relatifs à l'architecture. memoires de mathematique et de physique, présénts a l' académeie royale des sciences, par divers savans, et lûs dans ses assemblées, Paris.

Duncan, J. M. \& Chang, C. M. (1970). Nonlinear Analysis of Stress and Strain in Soils. Journal of soil Mechanics and Fondations Division, ASCE, 96(5), $1629-1653$.

Harata, N., Otani, J., Ochiai, H., Onda, K. \& Okuda, Y. (2009). Countermeasures Against Settlement of Embankment on Soft Ground with PFS (Partial Floating Sheet-Pile) Method. Geotechnics of Soft Soil - Focus on Ground Improvement - Karstunen \& Leoni, 345-351.

Kondner, R. L. (1963). Hyperbolic Stress-Strain Response: Cohesive Soils. Journal of the Soil Mechanics and Foundations Division, ASCE, 89(1), 115-143.

Mohr, O. (1990). Welche Umstände bedingen die Elastizitätsgrenze und den bruch eines materials?. Zeitschrift des vereines deutscher ingenieure, 44, 1524-1530, 1572-1577.

Manggada, R. B., Sofandi, P.S. \& Widiyono, R. A. (2015). Analisis Perkuatan Timbunan di Atas Tanah Lunak Menggunakan Geotextile. Geo-Challenge Competition (Foundation on Reinforced Soft-Soils), Universitas Atma Jaya Yogyakarta.

Schanz, T., Vermeer, P. A., \& Bonnier, P. G. (1998). Special Issue on Pre-Failure Deformation Behavior of Geomaterials. Geotechnics, 383-387.

Schanz, T., Vermeer, P. A., \& Bonnier, P. G. (1999). The Hardening Soil Model: Formulation and Verification. In Proceedings of the Plaxis Symposium: Beyond 2000 in Computational Geotechnics, 281-290.

Schweiger, H. F. (2009). Influence of Constitutive Model and EC7 Design Approach in FEM Analysis of Deep Excavations. Paper presented of ISSMGE Int. Seminar on Deep Eccavations and Retaining Structures, 99-114.

Tan, Y. C. (2005). Embankment Over Soft Clay Design and Construction Control. Geotechnical Engineering, 1-15. 